\title{
SPLEEN VOLUME EVOLUTION IN COURSE OF ACTH-ECTOPIC SYNDROME DUE TO PANCREATIC NEUROENDOCRINE TUMOR LIVER METASTASES. A CASE REPORT AND LITERATURE REVIEW
}

\author{
Shorikov M.A., Sergeeva O.N., Virshke E.R., Panov V.O., Dolgushin B.I.
}

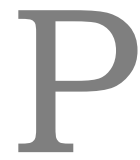

urpose. The paper is based on a seven-year surveillance of the patient showing ectopic adrenocorticotropic hormone (ACTH) syndrome.

Materials and methods. A female 49-year old patient underwent pancreaticoduodenectomy for pancreatic head neuroendocrine tumor (NET) with synchronous liver metastases in 2009. Over time the metastatic lesions were gradually enlarging and conventional transarterial chemoembolization (cTACE) was performed twice: on December 2012 and on March 2014 in "on demand" regimen. Since 2013 the patient developed clinical signs suspicious for hypercortisolism but the elevated serum cortisol and ACTH levels were registered only on May 2015. ACTH production was proven to be ectopic by dexamethasone suppression test and it was a quite rare finding in a pancreatic NET. At the same time the spleen volume on MRI was evaluated as $126 \mathrm{~cm} 3$ which was almost two times lower than in 2009 $(231 \mathrm{~cm} 3)$.

Results. With regard to occasional papers which mentioned cTACE as a method for hypercortisolism abatement the third cTACE was performed on June 2015. It resulted in tumor destruction, normalization of cortisol and ACTH levels and restoration of the spleen size, ongoing up to the date (12 months after the procedure). The retrospective MRI-based spleen volumetry demonstrated reduction of the spleen volume overall, and its increase in a period 1.5-12.0 months after each cTACE ( $\mathrm{r} 2=0.5, \mathrm{p}<0.006)$. The spleen volume also correlated with ACTH levels $(\mathrm{p}<0.0001)$. Thought a remarkable spleen weight decrease after prolonged dexamethasone treatment has been shown on rodent models, PubMed search revealed no previous clinical reports focusing on splenic volume evolution depending on glucocorticoid levels.

Conclusions. The presented case makes us hypothesize that the consistent pattern similar to that in the animal studies is also present in humans and, thus, microsplenia in cancer patients may serve as an indirect visualization sign of the ectopic ACTH production.

Keywords: spleen, neuroendocrine tumors, chemoembolization, ACTH-ectopic syndrome, MRI, volumetry.

Corresponding author: Shorikov M.A. mshorikov@gmail.com

For citation: Shorikov M.A., Sergeeva O.N., Virshke E.R., Panov V.O., Dolgushin B.I. Spleen volume evolution in course of ACTH-ectopic syndrome due to pancreatic neuroendocrine tumor liver metastases. A case report and literature review. REJR. 2016; 6 (3):108-116. DOI:10.21569/2222-7415-2016-6-3-108-116.

Received: 29.06.2016

Accepted: 13.07.2016
N.N. Blokhin Russian Cancer Research Center, Research Institute of Clinical and Experimental Radiology. Moscow, Russia. 


\section{АИНАМИЧЕСКОЕ ИЗМЕНЕНИЕ ОБЪЕМА СЕАЕЗЕНКИ ПРИ АКТГ- ЭКТОПИРОВАННОМ СИНАРОМЕ, ОБУСАОВАЕННОМ МЕТАСТАЗАМИ НЕЙРОЭНАОКРИННОЙ ОПУХОАИ ГОАОВКИ ПОАЖЕАУАОЧНОЙ ЖЕАЕЗЫ В ПЕЧЕНИ}

\author{
Шориков М.А., Сергеева О.Н., Виршке Э.Р., Панов В.О., Аолгушин Б.И.
}

$\mathrm{P}$

езюме. Работа основана на данных семилетнего динамического наблюдения за пациенткой, страдающей АКТГ-эктопированным синдромом.

Материалы и методы. В 2009 году больная в возрасте 49 мет перенесла панкреатодуоденальную резекцию по поводу нейроэндокринной опухоли (НЭО) головки поджелудочной железы с синхронными метастазами в печени. В дальнейшем отмечался рост метастатических очагов, в связи с чем в декабре 2012 года и марте 2014 года были проведены два сеанса масляной трансартериальной химиоэмболизации (ТАХЭ) печени в режиме "on demand". С 2013 года у больной наблюдались отдельные клинические проявцения гиперкортицизма, однако повышение уровня кортизола и АКТГ (адре-

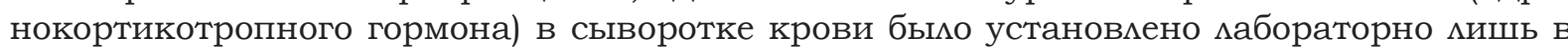
мае 2015 года. Дексаметазоновые пробы свидетельствовали в пользу наличия эктопического источника секреции АКТГ, что явцяется довольно редкой находкой при НЭО поджелудочной железы. При проведенной тогда же МРТ-волюмометрии объем селезенки составиц всего 126 см3, т.е. был почти в 2 раза меньше, чем при исходном исследовании от 2009 года $(231 \mathrm{~cm} 3)$.

Резумьтаты. С учетом единичных упоминаний в Аитературе о ТАХЭ как о способе уменьшения проявлений гиперкортицизма, в июне 2015 года был проведен третий сеанс ТАХЭ печени. В результате вмешательства опухолевые узмы подверглись деструкции, было отмечено восстановцение объема селезенки и нормализация уровней кортизола и АКТГ, сохраняющиеся на момент написания статьи (12 месяцев после интервенционного вмешательства). Ретроспективная МРТ-волюмометрия выявила общую тенденцию к уменьшению объема селезенки с течением времени при его увеличении в сроки от 1,5 до 12,0 месяцев посме каждого сеанса ТАХЭ печени ( $\mathrm{r} 2=0.5, \mathrm{p}<0.006)$. Объем селезенки также коррелировал с уровнем АКТГ ( $<<0.0001)$. Хотя в экспериментах на животных было показано, что у мышей и крыс после длительного систематического воздействия дексаметазона отмечалось значительное уменьшение массы селезенки, клинических исследований, направленных на изучение аналогичной взаимосвязи, в медицинской базе PubMed нам обнаружить не удалось.

Выводы. Представленный случай позволяет предположить, что зависимость, сходная с описанной в цабораторных исследованиях, существует и у мюдей, $а$, следовательно, уменьшение селезенки при опухолевом поражении может быть косвенным визуализационным признаком наличия эктопической продукции АКТГ.

КАючевые слова: селезенка, нейроэндокринные опухоли, химиоэмболизация, АКТГ-эктопированный синдром, МРТ, волюмометрия.

Контактный автор: Шориков М.A. mshorikov@gmail.com

Для иитирования: Шориков М.А., Сергеева О.Н., Виршке Э.Р., Панов В.О., Долгушин Б.И. Динамическое изменение объема селезенки при актг-эктопированном синдроме, обусловленном метастазами нейро-эндокринной опухоли головки поджелудочной железы в печени. REJR. 2016; 6 (3):108-116. DOI:10.21569/2222-7415-2016-6-3-108116.

Статья получена: 29.06.2016

Статья принята: 13.07.2016
ФГБУ «Российский онкологический научный центр имени Н.Н. Бмохина" Минздрава России. Научно-

Исследовательский Институт Клинической и Экспериментальной Радиологии.

г. Москва, Россия.

\section{ntroduction.}

The elevated plasma glucocorticoid levels, as it has been shown in animal studies, lead to a statistically significant (two- to threefold) spleen volume reduction due to both apoptosis of cells within the follicules and sinusoid thrombosis [1, 2]. In humans, hypercortisolism is caused by a large variety of reasons, e.g., glucocorticoid therapy, a hypophysis microadenoma, an adrenal cortex hyperplasia, an ACTH-ectopic syndrome, etc. 


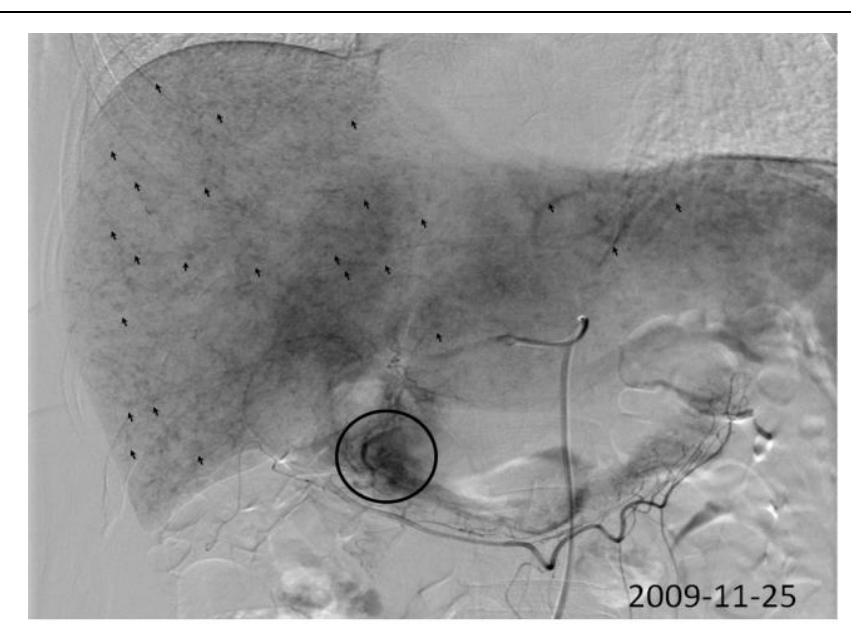

Fig. 1.

Fig. 1. Coeliacography (25.11.2009).

The black circle encompasses a pancreatic head NET, arrows point to miliary liver metastases.

[3]. Though it is not an uncommon condition in medical practice, we surprisingly found a lack of clinical reports describing the splenic changes in these diseases. Personally observing a rare case of ACTH-secreting liver metastases of a pancreatic head NET for 7 years we obtained 18 MRI-studies, which provided a basis to explore the connection between the tumor burden, hormone levels, treatment results and the spleen volume.

\section{A case report.}

A female 49 year old patient underwent pancreaticoduodenectomy for pancreatic head NET with multiple miliary liver metastases in 2009 (fig. 1). The pathologist diagnosis was a low grade NET (Grade 2, Mib-1 less than 7\%).

During the period since 2010 till 2012 the patient was treated with systemic chemotherapy including capecitabine, oxaliplatin and gemcitabine-based regimens. Follow-up abdominal MRI on 01.11.2012 demonstrated measurable metastases varying from 1.0 to $1.6 \mathrm{~cm}$ in the greatest dimension within the parenchyma of the Ist and the IVth liver segments along with the previously revealed miliary lesion (fig. 2).

On 19.21.2012 the patient underwent cTACE (lipiodol $7 \mathrm{ml}+$ doxorubicin $70 \mathrm{mg}$ ). The partial response was registered. On 04.03.2014 an additional cTACE (lipiodol $8 \mathrm{ml}+$ doxorubicin 80 $\mathrm{mg}$ ) was performed in "on demand" regimen (i.e., when more than $25 \%$ tumor re-growth was identified).

Though the patient demonstrated excessive pigmentation and stretchmarks highly suspicious for hypercotisolism since 2013, a lab testing failed to reveal elevated serum cortisol and ACTH levels. The patient was diagnosed with ACTH overproduction only on May 2015 when she developed a fullscale clinical picture of Cushing syndrome, con- sisting in a moon face, a "buffalo hump", a diffuse alopecia with a genian hypertrichosis, a lower limb swelling, a muscle weakness and a refractory arterial hypertension. Diagnostic work-up revealed steroid diabetes, prominent hypokalemia, elevated plasma ACTH $321.5 \mathrm{pg} / \mathrm{ml}$ (normal range 7.2 $63.3 \mathrm{pg} / \mathrm{ml}$ ) and cortisol - $53.5 \mathrm{pg} / \mathrm{ml}$ (normal range 6.2 - $19.4 \mathrm{pg} / \mathrm{ml}$ ); elevated free urine cortisol 4016 nmol per 24 hours (normal range 138.0 524.4 nmol per 24 hours). MRI of the pituitary gland didn't show any clear evidence of adenoma. The dexamethasone suppression test confirmed ectopic source of ACTH production.

The third cTACE (lipiodol $7 \mathrm{ml}+$ oxaliplatin $70 \mathrm{mg}$ ) was performed a month later (fig. 3).

After the third cTACE, the patient developed a rapidly progressive symptomatic response, including resolution of lower limb swelling, transient myalgia and diarrhea most likely due to plasma potassium recovery on the 2nd-3rd postprocedural days. One month later she showed the normal arterial pressure, the disappearance of the moon face and the "buffalo hump", the adequate muscle strength; and several months later less pigmentation and no genian hypertrichosis were evident. She is in a good condition a year later at the moment of the publication.

The disease course was followed by $18 \mathrm{ab}-$ dominal MRI since 2009 till 2016. ACTH and cortisol levels were regularly measured only from May 2015 after the diagnosis of ACTH-ectopic syndrome had been established to the date.

The tumor burden was evaluated by the quantity and the linear sizes of metastatic lesions on T2weighted axial images (1.5 T, TR varied 36007000, TE varied 82-107, slice thickness varied 6-7 $\mathrm{mm}$, periodically rotated overlapping parallel lines with enhanced reconstruction (PROPELLER) technique was used).

Due to a slow pattern of the metastatic growth we compared MRI studies performed at wide time intervals for better lesion size estimation. Surprisingly we caught sight of prominent splenic volume changes over time. We quantified our observation with the retrospective spleen volumetry using the same type of images by measuring surface of the spleen on each slice, adding them together and multiplying by slice thickness.

It was an intriguing fact that the spleen volume changed almost twofold (1.83 times) in the course of the disease from $231 \mathrm{~cm} 3$ in 2009 to $126 \mathrm{~cm} 3$ in 2015 (fig. 4). That made us guess what the reason behind it is. In published papers [4-13] we found possible causes of the spleen volume reduction, they mostly include conditions with hyposplenism such as autoimmune diseases, immunosuppression (including immunosuppression after transplantation), hematologic diseases, splenic circulation disorders, celiac disease. All the conditions except the two latter were ruled out by an 


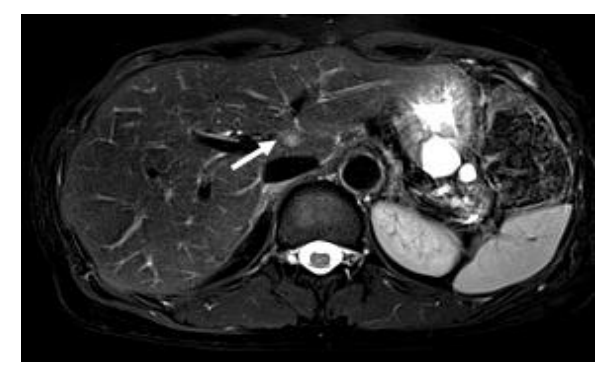

Fig. 2,a.

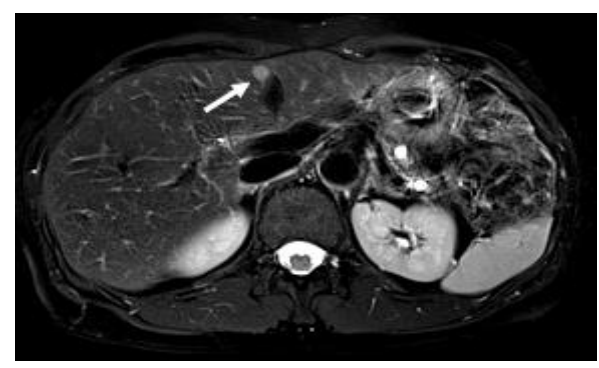

Fig. 2,b.

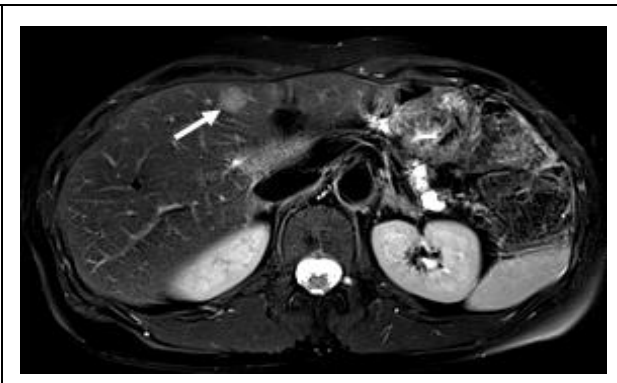

Fig. 2,c.

Fig. 2. MRI, fat saturated, T2-WI, periodically rotated overlapping parallel lines with enhanced reconstruction (01.11.2012).

Demonstrated metastases varying from 1.0 to $1.6 \mathrm{~cm}$ in the greatest dimension within the parenchyma of the Ist (a) and the IVth (b, c) liver segments (arrows).

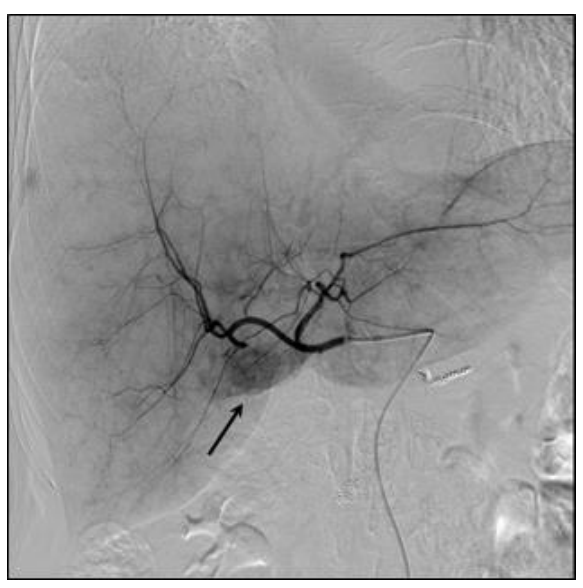

Fig. 3,a.

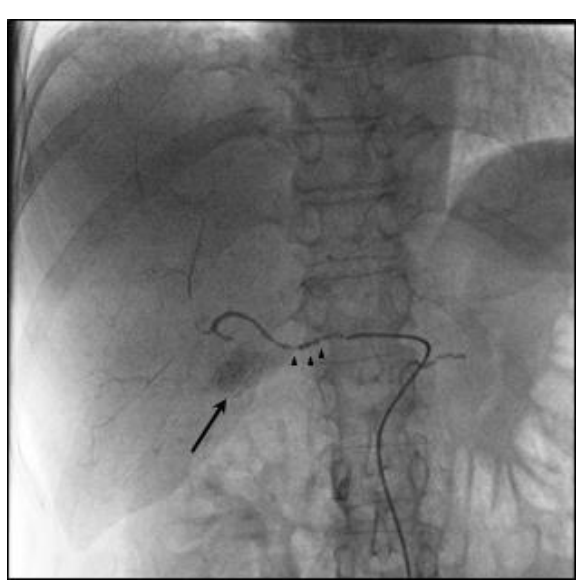

Fig. 3,b.

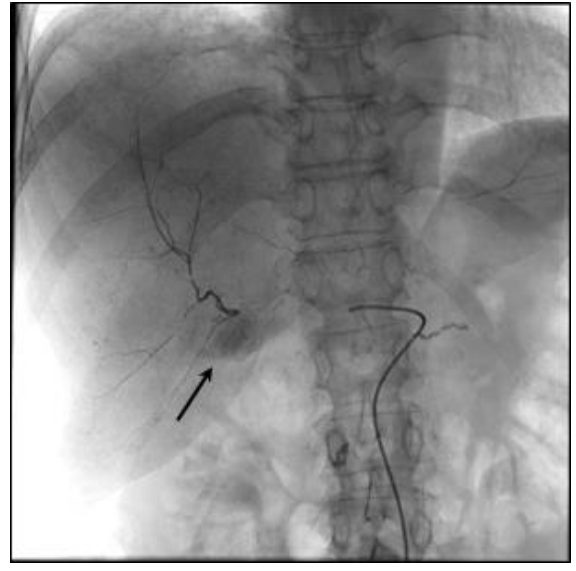

Fig. 3,c.

Fig. 3. CTACE (02.06.2015).

a - Hepaticoarteriography demonstrating the largest hypervascular lesion in the IV th liver segment (arrow);

b - Inraarterial injection of lipiodol with oxaliplatin (iodized oil drops are pointed by arrow heads) predominantly accumulated by metastatic lesion (arrow);

c - Post-procedural upper abdominal survey radiography showing tumoral accumulation of the iodized oil (arrow).

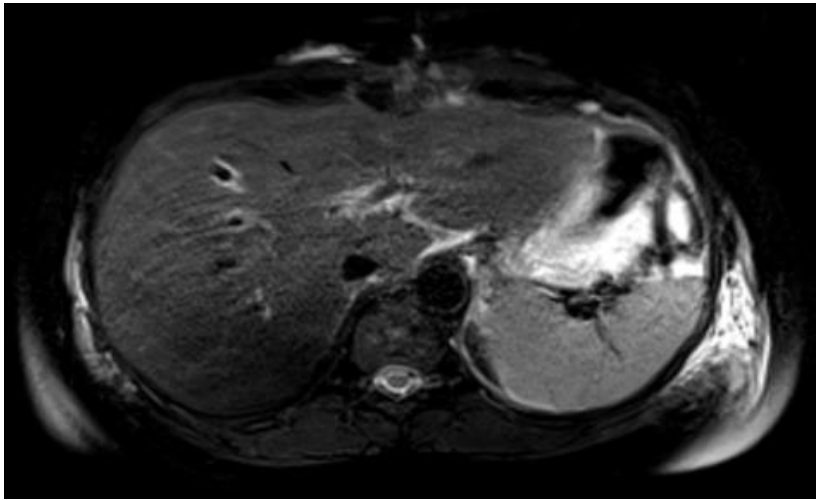

Fig. 4,a.

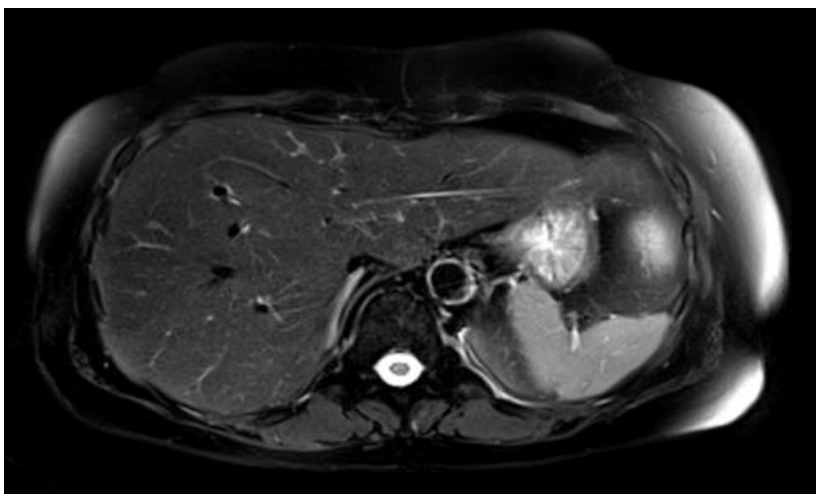

Fig. 4,b.

Fig. 4. MRI, fat saturated, T2-WI, periodically rotated overlapping parallel lines with enhanced reconstruction.

a - Comparison of the spleen size at the level of the hilus in 2009, adding them together and multiplying by slice thickness were $231 \mathrm{~cm} 3$;

b - On the corresponding splenic volumes evaluated by measuring surface of spleen on each slice in 2015, adding them together and multiplying by slice thickness were $126 \mathrm{~cm} 3$. 
amnestic data. The angiographic images performed on June 2015 revealed no evidence of the splenic circulation disorders (fig. 5).

The celiac disease was a likely diagnosis due to the presence of several symptoms: diarrhea, steatosis, dermatitis herpetiformis, diffuse alopecia, swelling of the lower extremities, osteoporosis, muscle weakness, weight loss, and anemia (all of these can also occur in Cushing syndrome patients). Nevertheless, either serological (IgA - 1.07 g/1 (normal range 0.4-3.5, antibodies to tissue transglutaminase: IgG - 0 relative units / ml (normal value <2.0), IgA - 1.93 relative units/1 (normal value <20), antibodies to endomysium (IgA) $-<1: 5$ (normal value $<1: 5$ ) or pathologist finding (histologic changes consistent with erosive enteritis, no evidence of celiac disease) exclude the celiac disease.

After the exclusion of the most probable non-neoplastic spleen reduction reasons we tried to find out if there's any connection between the tumor burden, hormone levels and the spleen size. The tumor response in consequence of the third cTACE is presented on the MRI performed before and after the procedure (fig. 6): the biggest metastasis within the IVth liver segment became hardly visible in December on T2WI. It was evident that the spleen size increased at the same time.

We also plotted changes of the spleen volume against relative (normalized to a mean of a normal range in each particular study) ACTH and cortisol levels (fig. 7): return of the hormone values into the normal range was accompanied by the spleen volume restoration from $126 \mathrm{~cm} 3$ to $192 \mathrm{~cm} 3$ (6 months period). Then after 9 months the volume was estimated as $178 \mathrm{~cm} 3$, after 12 months as $180 \mathrm{~cm} 3$.

Log-linear regression analysis showed that during the period since the last cTACE till June 2016 relative ACTH level was connected to the spleen volume as:

Relative ACTH = exp (6.22841$0.03380 *$ Spleen volume, cm3), $\mathrm{p}<0.0001$;

No connection to cortisol levels was found for the spleen volume $(p>0.05)$, levels of cortisol and ACTH were connected to each other as expected $(\mathrm{p}<0.0001)$.

Despite the fact that the study was limited by an unavailability of regular hormone measurements throughout the whole period of the surveillance the results of the volumetry might suggest the connection between cTACE response hormone levels and the spleen size. The retrospective spleen volumetry showed the spleen enlargement after each cTACE. It was confirmed by statistical analysis: the volume was significantly higher in a period 1.5-12.0 months after each cTACE with an overall volume reduction tendency (fig. 8 (a, b), regression analysis: r2=0.504, $\mathrm{p}<0.006)$. The similar effect was observed after chemotherapy but due to only single measurement wasn't statistically analyzed and confirmed for this type of treatment (fig. 8 a).

\section{Discussion and literature review.}

The normal size of the spleen is $198 \pm 88$ cm3 (20-90 years old volunteers) and it has a peak value at the age of $50-60$ and is evaluated in the same work as $221 \pm 95 \mathrm{~cm} 3$ [14]. Henderson J.M., et al. reported the size of the spleen in healthy volunteers group was $219 \pm 76 \mathrm{~cm} 3$ and varied $6-10 \%$ on different studies of the same person [15]. The measurements in these works were performed on CT-images and used the same method of the volume evaluation as we did. So, our patient's spleen volume decreased way below the mean of norm and at the very least to the minimum border of it. It changed by $83 \%$ during 2009-2015 period, which considerably excessed normal physiological fluctuation.

The published papers on the topic of the spleen size mostly discuss splenomegaly (spleen

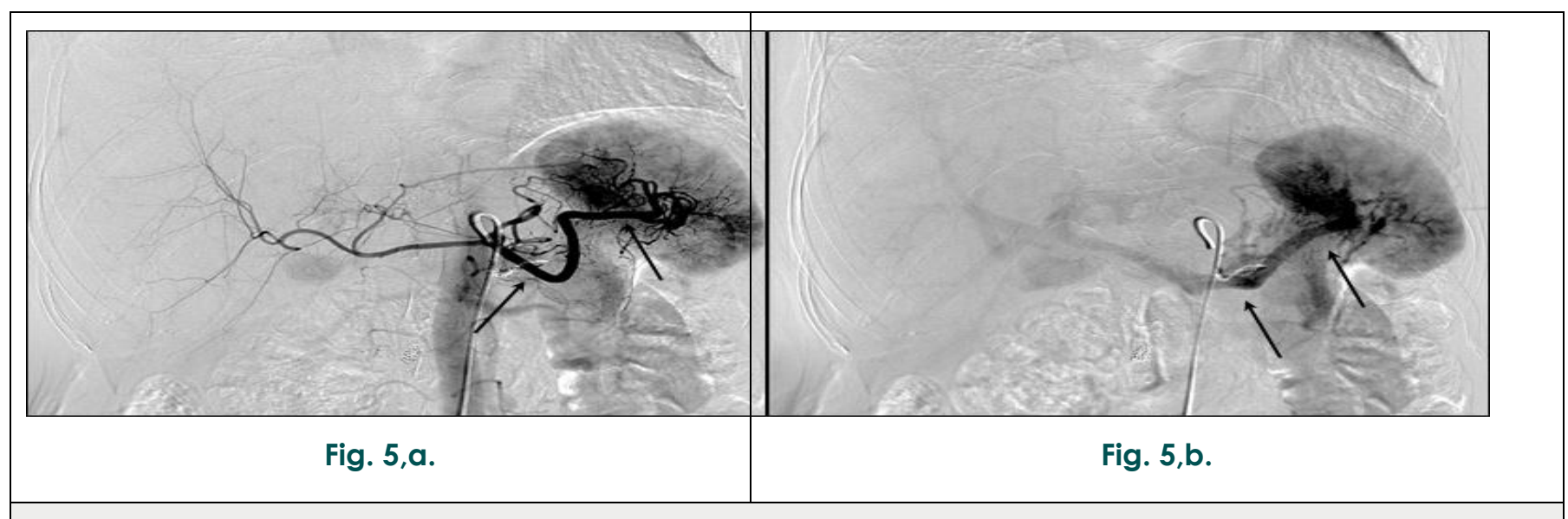

Fig. 5. a-Coeliacography. b-Arterial splenoportography.

Demonstrating unremarkable splenic artery and vein (arrows). 


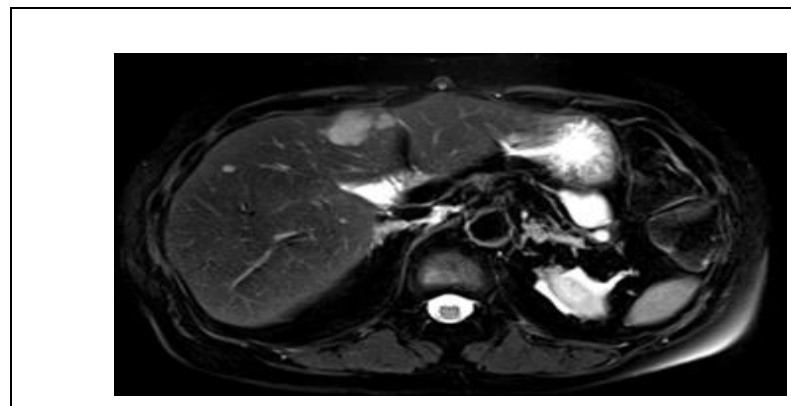

Fig. $6, a 1$

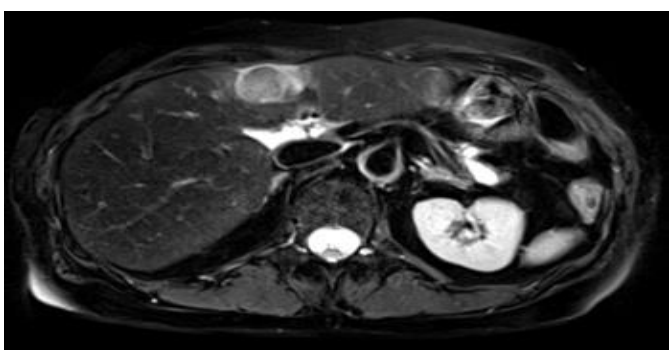

Fig. $6, a 2$

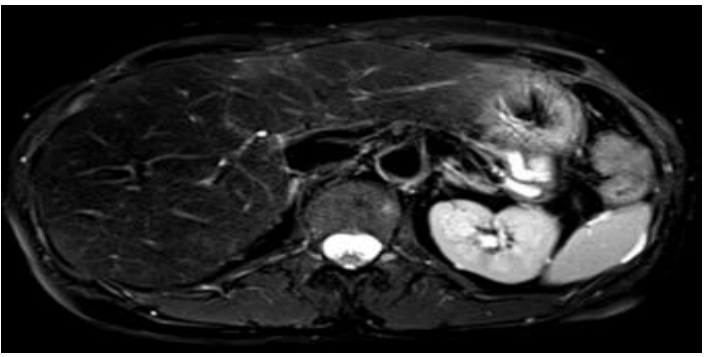

Fig. 6,a3

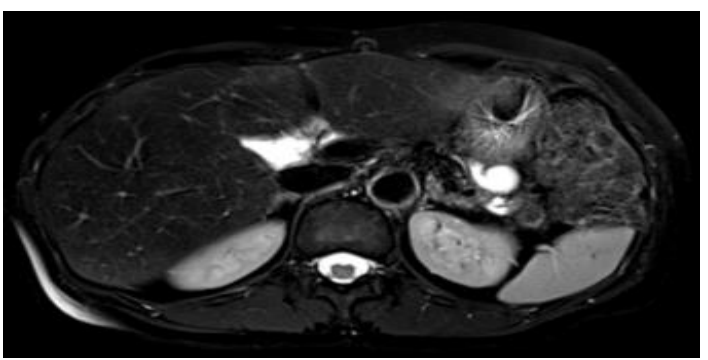

Fig. 6, a4

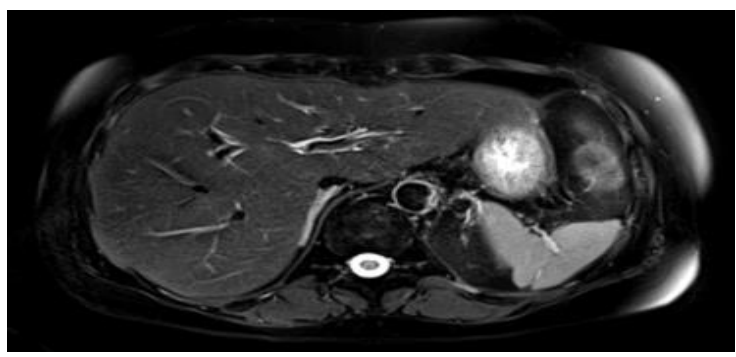

Fig. $6, b 1$

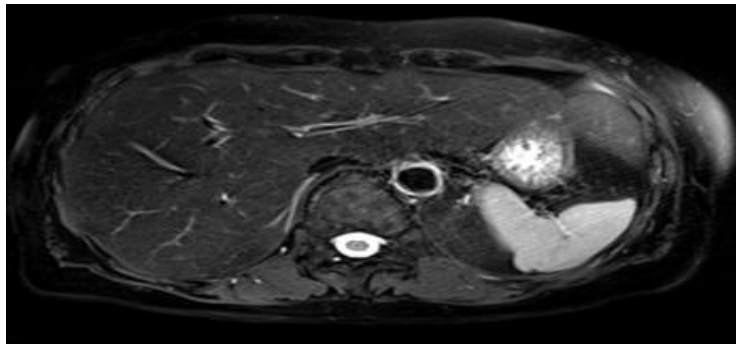

Fig. $6, b 2$

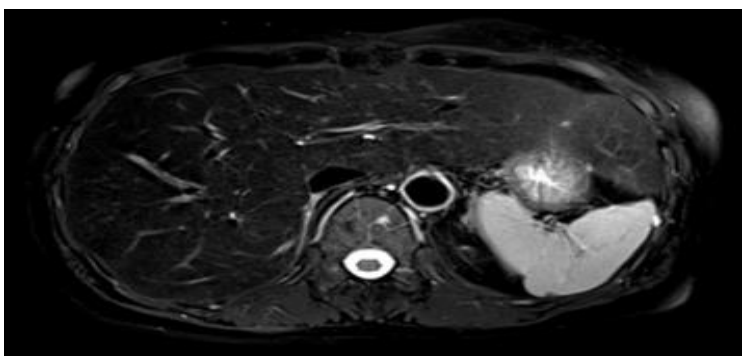

Fig. 6,b3

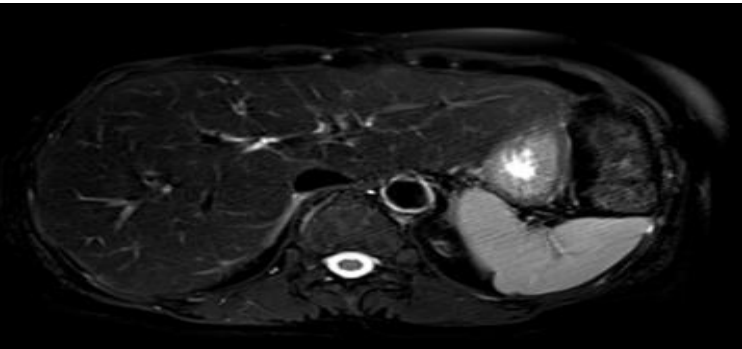

Fig. $6, \mathrm{~b} 4$

Fig. 6. MRI, fat saturated, T2-WI, periodically rotated overlapping parallel lines with enhanced reconstruction.

Reduction of tumor burden after c TACE accompanied by restoration of the spleen volume.

a - The largest metastasis within the IVth liver segment before cTACE (1 - May); post-TACE inflammatory changes 1 month later $(2$ - July); metastasis size reduction 6 (3- October) and 9 months (4- December) after cTACE.

b - Spleen at the level of the hilus before cTACE (1 - May, $126 \mathrm{~cm} 3) ; 1(2-\mathrm{July}, 128 \mathrm{~cm} 3), 6$ (3- October, 186 cm3) and 9 months (4- December, $192 \mathrm{~cm} 3$ ) after cTACE.

volume increase) with or without concomitant hypersplenism (overfunctioning), splenic hypotrophy is mentioned way less. Similar to splenomegaly and hypersplenism, microsplenia (spleen size reduction) and hyposplenism (diminished activity) are to be distinguished. This case study was limited by the incapability of the retrospective spleen function estimation, so we had to settle for spleen volumetry.
As it was quoted above the possible causes of the spleen volume reduction are autoimmune diseases, immunosuppression (including immunosuppression after transplantation), hematologic diseases, splenic circulation disorders, and celiac disease [4-13]. Some of them may first lead to splenomegaly followed by microsplenia and hyposplenism then. All of these conditions were ruled out in our case. 


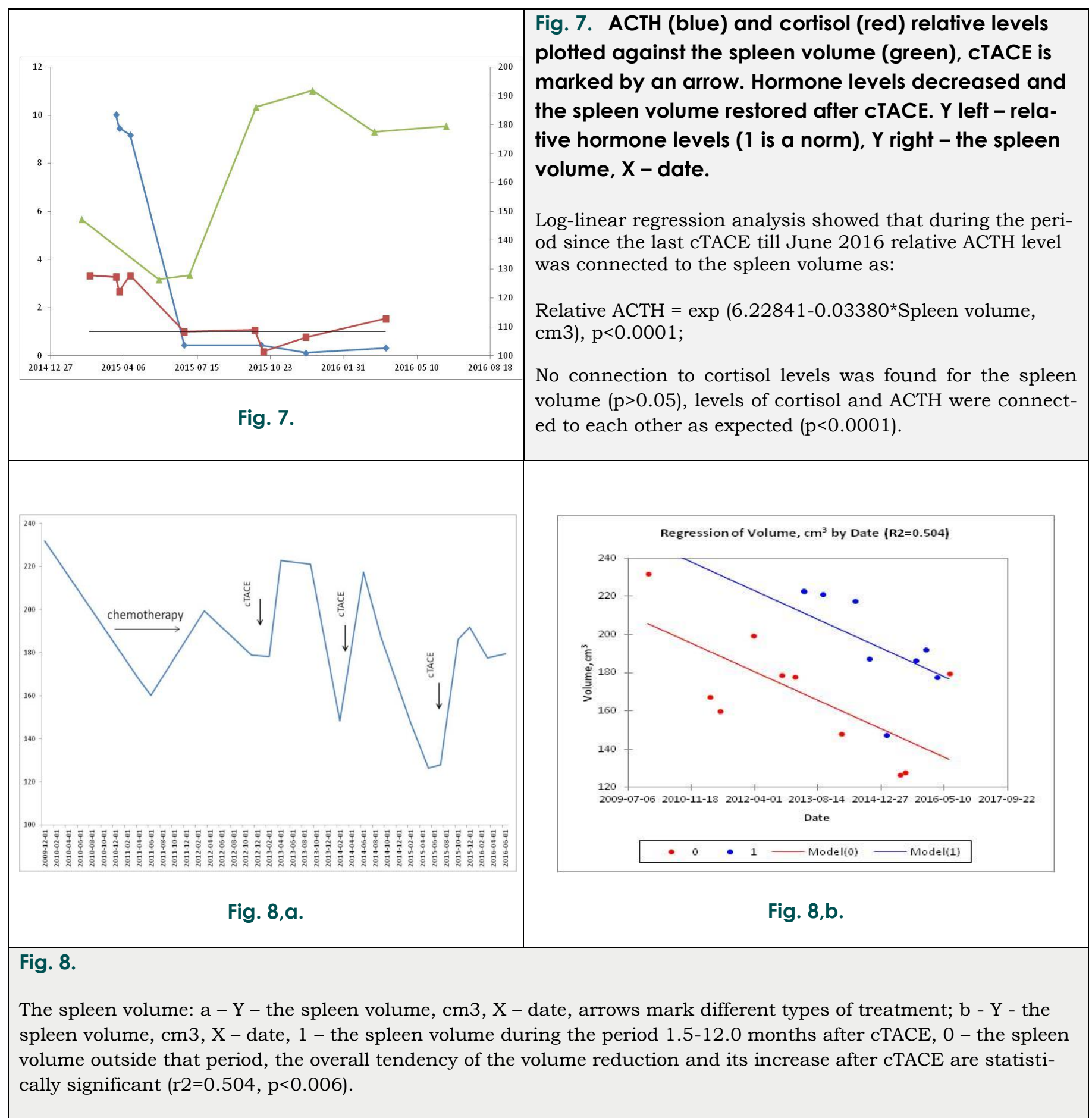

Previous publications didn't account human spleen volume reduction in relation to the elevated glucocorticoid levels with two exceptions: a case of glucocorticoid treated thrombocytopenic purpura [16] in which the strong connection is questionable and in a case of transplantation (mostly renal) but even here the spleen volume decrease is probably caused by mTOR inhibition effects [5].

In animals it was shown that glucocorticoid levels do reduce the spleen size. In rat experiments [1] the spleen weight decreased after dex amethasone treatment threefold in young animals and twofold in aged animals. Only in aged animal group the spleen fully restored after rehabilitation period. All the differences were statistically significant $(p<0.05)$. In another study performed on mice the similar results occurred: the spleen decreased after glucocorticoid treatment [2]. The histological findings demonstrated that the spleen size reduc tion was a result of both apoptosis of cells within the follicles and sinusoid thrombosis.

In humans the chronic cortisol overproduction causes Cushing's syndrome. It is a relatively rare (2-3/1000000/year) disorder characterized by a number of typical clinical signs such as rapid weight gain, central obesity, "buffalo hump", "moon face", excess sweating, dilation of capillaries, thinning of the skin and mucous membranes, purple or red striae on the trunk, buttocks, arms, 
legs, or breasts, proximal muscle weakness, hirsutism, baldness or brittle hair, hypocalcemia [3, 17]. It may lead to systemic complications resulted in a significant morbidity, an impaired life quality, and an increased mortality when cortisol levels are not controlled [18]. In most cases (80\%) Cushing's syndrome is ACTH-dependent [17, 19]. ACTH is produced by either a pituitary gland adenoma or a variety of malignancies, predominantly of neuroendocrine origin (bronchial, thymic, or pancreatic NETs), and also small cell lung carcinoma, phaeochromocytoma, medullary carcinoma of the thyroid and prostate carcinoma. Hypercortisolism due to tumor ACTH secretion is distinguished as ACTH-ectopic syndrome as it was in the presented case of the patient with pancreatic NET liver metastases.

ACTH-ectopic syndrome is an infrequent condition in NET patients. The analysis of a 20year large tertiary-care center experience revealed only 29 ACTH-secreting tumors, including 9 pancreatic only, among 918 NETs [18]. The overall pancreatic NETs frequency is estimated as 12/100000 cases. Hence pancreatic ACTHsecreting NETs are especially rare. There are only 135 cases to this day published in English since 1946 [20]. It is also hard to say at what stage of the disease and why exactly the syndrome occurs: in most cases it is easily diagnosed at the same time as the tumor, but there're cases when clinical picture and increased hormone levels are observed only 9-54 months after [18]. Liver metastases are seen in $75 \%$ of cases.

The 5-year survival rate of ACTH-secreting NETs of different organs and organ systems was statistically significantly lower $(\mathrm{p}<0.013)$ than other types of NETs [18].

A 5-year survival rate is only $35 \%$ in patients with ACTH-secreting pancreatic NETs compared to $97 \%$ of patients with insulinomas, $72 \%$ with gastrinomas, $75.2 \%$ with somatostatinomas, and $80 \%$ with nonfunctioning PanNETs. A 10 year survival rates are $16 \%$ for ACTH-secreting pancreatic NETS and $86 \%$ of patients for insulinomas, $59 \%$ for gastrinomas, and $67 \%$ for nonfunctioning PanNETs [20].

Taking all of the above into account we can conclude that ACTH-secreting NETs and especially pancreatic ones are understudied while being more dangerous than NETs of other kind.

Conservative management of ACTH-ectopic syndrome aims to break a link between ACTH and effector organs on different levels. To that end inhibitors of adrenal cortical function (ketokonazol) and steroid production (metyrapone), glucocorticoid antagonists (mifepristone), adrenolitics (mitotane), somatostatin analogs (octreotide acetate) are used. Nevertheless, drug therapy often demonstrates low efficiency; adrenalectomy is required in $75 \%$ of the patients [18].

Pubmed search revealed only two cases of cTACE performed for pancreatic NET-related Cushing's syndrome abatement purpose.

In one of the cases [21] a 64-year old woman was diagnosed with initially asymptomatic pancreatic head tumor. Six years later she developed Cushing syndrome and the liver metastases were identified on CT-scan. The patient wasn't suitable for curative surgery and thus was treated with multiple cTACEs and octreotide therapy. She was alive without hypercortisolism signs 20 months later.

In the second case [22] a 71-year old man got the same treatment but it was ineffective and adrenalectomy was performed, after which the patient died because of complications.

The splenic volume changes weren't assessed in the mentioned papers.

So, the presented case is described in three "rare": rare disease (ACTH-producing liver metastases of pancreatic NET), rare visualization finding (spleen evolution depending on ACTH levels) and rare management (successful cTACE for abatement of Cushing syndrome).

The scaling-down splenic evolution was previously regarded as a visualization sign of unknown significance. The consistent pattern of connection between glucocorticoid levels and spleen volume changes in the presented case appears similar to that in animal studies $[1,2]$. Thus, we suppose that microsplenia may hint at hypercotisolism if other possible causes are excluded. Nevertheless, further studies are required to confirm our hypothesis.

\section{References:}

1.Orzechowski A., Ostaszewski P., Wilczak J., Jank M., BaEAsiŃSka B., WarESki P. et al. Rats with a GlucocorticoidInduced Catabolic State Show Symptoms of Oxidative Stress and Spleen Atrophy: The Effects of Age and Recovery. Journal of Veterinary Medicine Series A. 2002; 49 (5): 256-63.

2.Rungruang T., Chaweeborisuit P., Klosek S.K. Effect of malaria infection and dexamethasone on spleen morphology and histology. The Southeast Asian journal of tropical medicine and public health. 2010 ; 41 (6): 1290-6.

3. Chabre O. Syndromes de Cushing : physiopathologie, étiologie

et principes thérapeutiques. La Presse Médicale. 2014 4; 43 (4/1): 376-92.

4.Al-Eid M.A., Tutschka P.J., Wagner H.N. Jr., Santos G.W., Tsan M.F. Functional asplenia in patients with chronic graftversus-host disease: concise communication. Journal of nuclear medicine : official publication, Society of Nuclear Medicine. 1983; 24 (12): 1123-6.

5.Araujo N.C., Sampaio Goncalves de Lucena S.B., da Silveira Rioja S. Effect of rapamycin on spleen size in longstanding renal transplant recipients. Transplantation proceedings. 2014; 46 


\section{RUSSIAN ELECTRONIC JOURNAL OF RADIOLOGY}

\section{(5):1319-23.}

6.Atkinson K., Storb R., Prentice R.L., Weiden P.L., Witherspoon R.P., Sullivan K. et al. Analysis of late infections in 89 long-term survivors of bone marrow transplantation. Blood. 1979; 53 (4): 720-31.

7.Brousse V., Buffet P., Rees D. The spleen and sickle cell disease: the sick(led) spleen. British Journal of Haematology. 2014; 166 (2): 165-76.

8.Chikamori F., Nishida S., Selvaggi G., Tryphonopoulos P., Moon J.I., Levi D.M. et al. Effect of liver transplantation on spleen size, collateral veins, and platelet counts. World journal of surgery. 2010; 34 (2): 320-6.

9.Ferguson A., Hutton M., Maxwell J.D., Murray D. Adult coliac disease in hyposplenic patients. The Lancet. 1970; 295 (7639): 163-4.

10.Halfdanarson T.R., Litzow M.R., Murray J.A. Hematological manifestations of celiac disease. Blood. 2007; 109 (2): 412-21.

11.Santos N., Silva R., Rodrigues J., Torres-Costa J. Sjogren's syndrome and acquired splenic atrophy with septic shock: a case report. Journal of medical case reports. 2014; 8:10.

12.William B.M., Corazza G.R. Hyposplenism: A comprehensive review. Part I: Basic concepts and causes. Hematology. 2007; 12 (1): 1-13.

13. William B.M., Thawani N., Sae-Tia S., Corazza G.R. Hyposplenism: A comprehensive review. Part II: Clinical manifestations, diagnosis, and management. Hematology. 2007; 12 (2): 89-98.

14.Caglar V., Alkoc O.A., Uygur R., Serdaroglu O., Ozen O.A. Determination of normal splenic volume in relation to age, gender and body habitus: a stereological study on computed tomography. Folia morphologica. 2014; 73 (3): 331-8.

15.Henderson J.M., Heymsfield S.B., Horowitz J., Kutner M.H. Measurement of liver and spleen volume by computed tomography. Assessment of reproducibility and changes found following a selective distal splenorenal shunt. Radiology. 1981; 141 (2): 525-7.
16.Dekker P.T., Propp R.P. Functional asplenia in idiopathic thrombocytopenic purpura. New York state journal of medicine. 1977; 77 (14): 2282-5.

17.Lacroix A., Feelders R.A., Stratakis C.A., Nieman L.K. Cushing's syndrome. Lancet (London, England). 2015 29; 386 (9996): 913-27.

18.Kamp K., Alwani R.A., Korpershoek E., Franssen G.J., de Herder W.W., Feelders R.A. Prevalence and clinical features of the ectopic ACTH syndrome in patients with gastroenteropancreatic and thoracic neuroendocrine tumors. European journal of endocrinology European Federation of Endocrine Societies. 2016; 174 (3): 271-80.

19.de Herder W.W., Krenning E.P., Malchoff C.D., Hofland L.J., Reubi J.C., Kwekkeboom D.J. et al. Somatostatin receptor scintigraphy: its value in tumor localization in patients with Cushing's syndrome caused by ectopic corticotropin or corticotropinreleasing hormone secretion. The American journal of medicine. 1994; 96 (4): 305-12.

20.Maragliano R., Vanoli A., Albarello L., Milione M., Basturk O., Klimstra D.S. et al. ACTH-secreting Pancreatic Neoplasms Associated With Cushing Syndrome: Clinicopathologic Study of 11 Cases and Review of the Literature. The American Journal of Surgical Pathology. 2015; 39 (3): 374-82.

21.Kondo T., Matsuyama R., Ashihara H., Matsuo Y., Sasaki K., Goto R. et al. A Case of Ectopic Adrenocorticotropic Hormoneproducing Pancreatic Neuroendocrine Tumor with Multiple Liver Metastases. Endocrine Journal. 2010; 57 (3): 229-36.

22.Vaduganathan M., Nagarur A., Kerr D.A., Lauter K.B., Padmanabhan A., Raghavan S. et al. Metastatic pancreatic neuroendocrine tumor with ectopic adrenocorticotropic hormone production. Proceedings (Baylor University Medical Center). 2015; 28 (1): 46-9. 